\title{
Strategi Musyrif Dalam Membentuk Karakter Kepemimpinan dan Kemandirian Siswa Boarding School
}

\author{
Muhammad Khairul Basyar \\ Pascasarjana UIN Sunan Ampel Surabaya \\ E-mail: khobarirul@gmail.com
}

Naskah diterima: 2 Maret 2020, direvisi: 12 Maret 2020, disetujui: 24 Maret 2020

\begin{abstract}
Abstrak
Tujuan daripada penelitian ini adalah untuk mendeskripsikan bagaimana strategi Musyrif dalam membentuk karakter kepemimpinan dan kemandirian siswa Boarding School. Penelitian ini mengambil studi kasus di SMA Insan Cendekia Mandiri Boarding School (ICMBS), Sidoarjo. Metode yang digunakan dalam penelitian ini adalah penelitian kualitatif. Data diperoleh melalui observasi, dokumentasi dan in-depth interview dengan key informant: Supervisor Asrama SMA ICMBS, Musyrif, siswa, dan Alumni. Adapun teknik analisis data yang digunakan adalah teknik analisis deskriptif. Berdasarkan hasil penelitian dapat dikonklusikan: (1) Strategi Musyrif dalam membentuk karakter kepemimpinan dan kemandirian terbagi dua yaitu internal dan eksternal. (2) Strategi internal meliputi enam tahapan yaitu: perencanaan, pengenalan, pelaksanaan, pengawasan, reward and punishment, dan evaluasi. Perencanaan diintegrasikan melalui organizing divisi kepengurusan asrama. Pengenalan diintegrasikan melalui pembelajaran diniyah, Taujihat Wal Irsyadat, pendidikan keorganisasian, dan keteladanan. Pelaksanaan diintegrasikan melalui kegiatan Organisasi Asrama Santri, multi activities, dan kedisiplinan. Pengawasan diimplementasikan oleh seluruh komponen lembaga pendidikan. Reward and punishment diintegrasikan sesuai prinsip dan ketetapan yang berlaku. Evaluasi diintegrasikan melalui rapat Musyrif, Musyrif dengan siswa, dan ujian diniyah. (3) Strategi eksternal meliputi pengenalan, pengawasan, dan evaluasi yang diintegrasikan melalui komunikasi aktif dengan orang tua wali baik dalam bentuk formal maupun nonformal.
\end{abstract}

Kata-kata kunci: Strategi, Musyrif, Karakter Kepemimpinan Dan Kemandirian

\section{Abstract}

The purpose of this research is to describe how Musyrif's strategy in shaping the character of leadership and independence student at high school ICMBS Sidoarjo. This research takes a case study in high school Insan Cendekia Mandiri Boarding School (ICMBS), Sidoarjo. The method which used in this research is qualitative. The Data obtained through observation, documentation and indepth interviews with key informants they are: Boarding Supervisor, Musyrif, student and Alumni. The technique of data analysis which used is by descriptive analysis techniqu. Based on the results of the study it can be concluded: (1) The Musyrif's strategy in shaping the character of leadership and independence is divided into two, internal and external. (2) The internal strategy includes six steps, they are: planning, knowing, actuating, controlling, reward \& punishment, and evaluating. The planning strategy is integrated through organizing the division of management. The knowing strategy is integrated through the learning of diniyah, taujihat wal irsyadat, leadership education, and model. The actuating strategy is integrated through the organization of Boarding School, multi activities, and discipline. The controlling strategy is carried out by all components high school ICMBS Sidoarjo. The Reward and punishment strategy are carried out by principles and provisions. The evaluation strategy is integrated through the evaluation between Musyrif, Musyrif and students, and the examination of diniyah. (3) The external strategy includes three steps they are: knowing, controlling, and evaluation which is integrated through effective communication with the guardian's parents by formal or informal.

Keywords: Strategy, Musyrif, The Character Of Leadership and Independence. 


\section{Pendahuluan}

Krisis karakter kepemimpinan dalam berbagai tingkat di negeri ini telah menjadi perbincangan yang hangat. Jumlah Kasus Berdasarkan Modus Korupsi (2019) Sumber : Indonesian Corruption Watch (ICW), 18 Februari 2020. Daftar urutan modus dari yang paling banyak dilakukan adalah:

$\begin{array}{ll}\text { 1. } & \text { Suap } \\ \text { 2. } & \text { Mark up } \\ \text { 3. } & \text { Penyalahgunaan wewenang } \\ \text { 4. } & \text { Kegiatan/proyek fiktif } \\ \text { 5. } & \text { Laporan fiktif } \\ \text { 6. } & \text { Pungutan liar } \\ \text { 7. } & \text { Gratifikasi } \\ \text { 8. } & \text { Pemerasan } \\ \text { 9. } & \text { Penyunatan/pemotongan } \\ \text { 10. } & \text { Mark down }\end{array}$

Suap adalah modus yang paling banyak ditemui dalam pengusutan kasus korupsi. Setidaknya terdapat 51 kasus korupsi dengan penyuapan. Nilai suap sebesar Rp 169,5 miliar sedangkan pencucian uang sebanyak $\mathrm{Rp} 46$ miliar.

Modus penyalahgunaan wewenang berjumlah 30 kasus. Jumlah tersebut memang tak sebanyak suap, namun nilai kerugian negara yang ditimbulkan mencapai Rp 6,3 triliun. Nominalnya sekaligus yang terbesar dibandingkan modus lainnya (Penulis: Yosepha Pusparisa, Editor: Safrezi Fitra, 19/2/2020, 08.00 WIB, pada databoks.katadata.co.id).

Realitas tersebut mengindikasikan betapa buruknya karakter yang dimiliki oleh pemimpin tersebut. Karakter seorang pemimpin, menginterpretasikan cara dia memimpin bawahannya serta orang-orang yang ada di bawah pengaruhnya. Karena itu tidak cukup pemimpin hanya memiliki kualitas intelektual mumpuni, tapi juga harus dilandasi karakter yang kompatibel. Dalam banyak terminologi, leader atau pemimpin bisa mencakup penghulu, pemuka, pelopor, pembimbing, pengarah, panutan, tokoh, kepala, penuntun, raja, ratu, yang dituakan dan lainlainnya (Rivai, Bachtiar, \& Amar, 2013).

Selain krisis karakter kepemimpinan, krisis perkelahian massal, tawuran, balapan liar, penggunaan narkoba, minum-minuman keras ditambah lagi dengan banyaknya pengangguran daripada lulusan berpendidikan formal menyebabkan banyak pihak yang menuntut agar lembaga pendidikan sebagai lembaga resmi pendidik generasi bangsa agar dapat mengeskalasikan peran dan tugasnya dalam membentuk karakter generasi bangsa.

Dalam upaya memenuhi berbagai tuntutan, lembaga pendidikan terus melakukan inovasi dalam berbagai aspek, mulai strategi pendidikan dan pembelajaran yang digunakan, aspek karakter yang diunggulkan, kompetensi yang wajib dimiliki oleh peserta didik, kegiatan ekstrakurikuler, dan multi ragam lainnya dalam rangka menciptakan Sumber Daya Manusia yang berkualitas dan mumpuni. Upaya ini sejalan dengan amanat Undang-Undang Nomor 20 Tahun 2003, Bab 1 Pasal 1 Ayat 1, bahwa "Pendidikan adalah usaha sadar dan terencana untuk mewujudkan suasana belajar dan proses pembelajaran agar peserta didik secara aktif mengembangkan potensi dirinya untuk memiliki kekuatan spiritual keagamaan, pengendalian diri, kepribadian, kecerdasan, akhlak mulia, serta keterampilan yang diperlukan dirinya, masyarakat, bangsa dan negara". Jadi pendidikan adalah usaha untuk memajukan peradaban suatu bangsa sehingga menjadi lebih bermartabat.

Untuk itu, dalam membentuk karakter dibutuhkan usaha pembentukan karakter secara menyeluruh. Pembentukan karakter secara 
menyeluruh akan menciptakan pemimpin yang berkarakter dan generasi yang mandiri sehingga tidak ada lagi krisis karakter kepemimpinan dan kemandirian di negeri ini. Untuk membentuk karakter secara menyeluruh dibutuhkan pengajaran dan pembiasaan dengan bimbingan secara intens. Menurut Aynur Pala karakter seseorang tidak terbentuk secara otomatis, melainkan melalui proses dari waktu ke waktu dan harus dilaksanakan secara efektif dan komprehensif (Pala, 2011).

Proses pembentukan karakter dalam dunia pendidikan dikenal dengan pendidikan karakter. Pendidikan karakter merupakan kegiatan pembentukan kecerdasan dalam berfikir dan bertindak, penghayatan dan kepedulian dalam bentuk sikap dan tindakan, pengamalan dalam bentuk perilaku sesuai dengan norma dan nilai-nilai mulia, yang termanifestasi dalam bentuk interaksi kepada tuhannya, kepada masyarakat dan kepada dirinya sendiri. Adapun nilai-nilai mulia yang dibentuk adalah kejujuran, kemandirian, sopan santun, tata krama, sosialis, berpikir dan bertindak logis, serta memiliki sifat antusias dalam ilmu pengetahuan. Pembentukan nilainilai ini membutuhkan proses yang didukung dengan suri tauladan yang baik, lingkungan, sekolah, dan keluarga (Zubaedi, 2011).

Dalam membentuk karakter peserta didik, strategi yang efektif dan efisien adalah sesuatu yang sangat imperative. Strategi adalah perencanaan yang berisi tentang rangkaian kegiatan yang didesain sedemikian rupa untuk mencapai tujuan yang diinginkan. Sebagaimana halnya dalam peperangan diperlukan berbagai pertimbangan, baik internal maupun eksternal, seperti siasat, taktik, dan teknik apa yang akan digunakan dalam peperangan, seberapa besar kualitas dan kuantitas kekuatan musuh, kapan dan dimana penyerangan akan dilakukan.
Semua itu dilakukan agar tercapai keberhasilan dan kemenangan (Zainiyati, 2010).

Berbagai penelitian menunjukkan bahwa pendidikan berbasis Boarding School mampu membentuk karakter peserta didik dengan baik diantaranya; Anisa Rizkiani yang meneliti pengaruh sistem Boarding School terhadap pembentukan karakter peserta didik (Rizkiani, 2012). Penelitian dilakukan di Ma'had Darul Arqam Muhammadiyah Daerah Garut. Hasil penelitian menunjukkan korelasi yang tinggi antara sistem Boarding School terhadap pembentukan karakter peserta didik (Ridwan \& Rusdiana, 2018). Hal senada juga diungkapkan dalam penelitian Hendriyenti terhadap pembinaan moral siswa di SMA Taruna Indonesia Boarding School Palembang, bahwa keberhasilan pembentukan karakter peserta didik tidak hanya dipengaruhi oleh pembina yang memiliki loyalitas tinggi, tapi juga dipengaruhi oleh sistem pengawasan dan pembinaan 24 jam di kawasan yang terisolir yang disebut dengan Boarding School ("Pelaksanaan Program Boarding School Dalam Pembinaan Moral Siswa Di Sma Taruna Indonesia Palembang," 2014). dengan demikian pendidikan berbasis boarding school merupakan salah satu strategi masa kini dalam membentuk karakter peserta didik.

$$
\text { Pendidikan Boarding School }
$$

sebenarnya merupakan pendidikan rumah atau keluarga yang diadopsi kedalam lembaga pendidikan dibawah manajemen dan kepemimpinan yang sistematis. Jika dalam rumah, pendidikan dilakukan langsung oleh kedua orang tua, sedangkan Boarding School dibimbing oleh pembina asrama atau yang dikenal dengan Musyrif (Farida Galela, 2012). Musyrif berasal dari kata Syarufa yang bermakna mulia, Al Musyrif maknanya pembimbing. Dalam konteks pendidikan Boarding School Musyrif adalah pendidik 
informal yang bertanggung jawab terhadap pendidikan diasrama (Wijaya, Andi, Wahidin, \& Maulida, 2018). Lembaga pendidikan berbasis Boarding School memfasilitasi peserta didiknya berupa asrama sebagai tempat tinggal untuk jangka waktu tertentu guna dididik dengan manajemen yang sistematis ("Pelaksanaan Program Boarding School Dalam Pembinaan Moral Siswa Di Sma Taruna Indonesia Palembang," 2014). Karena itu tidak heran banyak yang menerapkan strategi pendidikan berbasis Boarding School mulai dari tingkat Sekolah Dasar sampai Perguruan Tinggi (Suprawito, 2010).

Realitas bahwa pendidikan berbasis Boarding School menjadi tempat untuk membentuk pemimpin yang berkarakter dan mandiri memang tak dapat dipungkiri. Salah satunya adalah lembaga pendidikan SMA Insan Cendekia Mandiri Boarding School, Sidoarjo. Lembaga pendidikan yang berada dibawah naungan Yatim Mandiri ini telah berhasil memandirikan banyak anak yatim yang datang dari berbagai penjuru negeri ini sekaligus membentuk karakter kepemimpinan dalam diri siswanya. ("Dokumentasi Arsip SMA Insan Cendekia Mandiri Boarding School, Sidoarjo," 2019”)

Padahal menurut Ahmad Tafsir kondisi psikologi anak yatim yang ditinggal oleh ayahnya sejak kecil berbeda dengan mereka yang bukan anak yatim. Umumnya anak yatim mengalami banyak tekanan dan mental serta kurangnya kepercayaan diri. Banyak fenomena anak yatim yang mengalami hambatan dalam perkembangan. Menurutnya keyatiman telah menjadi salah satu penyebab rendah diri, dan rendah diri merupakan salah satu penyebab terhambatnya perkembangan (Tafsir, 2013). ini membuktikan kesuksesan SMA ICMBS dalam membentuk karakter kepemimpinan dan kemandirian siswanya.
Untuk mencapai hal tersebut, Lembaga Pendidikan Insan Cendekia Mandiri Boarding School merekrut Musyrif sebagai guru, pendidik, pembimbing, dan pengawas di Boarding School. Beberapa penelitian menunjukkan bahwa Musyrif memiliki peran sentral dalam membentuk karakter peserta didik di sekolah berbasis Boarding School. Salah satunya adalah penelitian yang dilakukan oleh Muhammad Andi Wijaya dkk, terkait upaya Musyrif dalam membentuk kepribadian Muslim di Ma'had Huda Islami Kabupaten Bogor Tahun 2018. Hasil penelitian menunjukkan bahwa Musyrif berperan besar dalam membentuk kepribadian Muslim yang berkarakter melalui pemberian pendidikan akidah yang benar, bimbingan agar siswa memiliki akhlak yang baik, berdisiplin dan giat beribadah, serta pemberian motivasi-motivasi yang mengarah pada pembentukan kepribadian muslim yang baik. Semua itu dilakukan dengan pengawasan oleh Musyrif hampir 24 jam (Wijaya et al., 2018).

Dalam membentuk karakter kepemimpinan dan kemandirian siswa SMA ICMBS, Musyrif memiliki strategi yang dianggapnya sangat efektif dan efisien. hal tersebut terdorong oleh keunikan sekolah SMA ICMBS sendiri dimana komponen peserta didiknya terbagi menjadi dua program; mandiri dan beasiswa. Program mandiri yaitu mereka yang membayar biaya pendidikan selama di SMA ICMBS Sidoarjo, sedangkan program beasiswa yaitu mereka anak yatim yang diberikan beasiswa untuk sekolah di SMA ICMBS Sidoarjo. Mengingat biaya pendidikan di SMA ICMBS Sidoarjo tergolong mahal, tentu mereka yang mampu membayar bukan berasal dari kalangan yang pas-pasan, demikian sebaliknya dengan mereka program beasiswa anak yatim, dimana mereka sudah ditinggal oleh ayahnya sejak kecil belum lagi kondisi 
ekonomi yang pas-pasan. Tujuan daripada penelitian ini adalah untuk mendeskripsikan bagaimana strategi Musyrif dalam membentuk karakter kepemimpinan dan kemandirian siswa Boarding School. Berdasarkan hasil penelitian dapat dikonklusikan: (1) Strategi Musyrif dalam membentuk karakter kepemimpinan dan kemandirian terbagi dua yaitu internal dan eksternal. (2) Strategi internal meliputi enam tahapan yaitu: perencanaan, pengenalan, pelaksanaan, pengawasan, reward and punishment, dan evaluasi. Perencanaan diintegrasikan melalui organizing divisi kepengurusan asrama. Pengenalan diintegrasikan melalui pembelajaran diniyah, Taujihat Wal Irsyadat, pendidikan keorganisasian, dan keteladanan. Pelaksanaan diintegrasikan melalui kegiatan Organisasi Asrama Santri, multi activities, dan kedisiplinan. Pengawasan diimplementasikan oleh seluruh komponen lembaga pendidikan. Reward and punishment diintegrasikan sesuai prinsip dan ketetapan yang berlaku. Evaluasi diintegrasikan melalui rapat Musyrif, Musyrif dengan siswa, dan ujian diniyah. (3) Strategi eksternal meliputi pengenalan, pengawasan, dan evaluasi yang diintegrasikan melalui komunikasi aktif dengan orang tua wali baik dalam bentuk formal maupun nonformal.

\section{Metode}

Jenis penelitian yang digunakan dalam penelitian ini adalah studi kasus. Studi kasus dalam penelitian ini adalah studi kasus observasi dimana pengambilan datanya peneliti ikut terlibat dalam suatu kegiatan atau participant observation sesuai dengan yang menjadi fokus penelitiannya.

Pendekatan dalam penelitian ini menggunakan pendekatan kualitatif. Tujuannya adalah untuk mendeskripsikan sekaligus mengungkap bagaimana strategi musyrif dalam membentuk karakter kepemimpinan dan kemandirian siswa SMA ICMBS sidoarjo. Adapun penyajian datanya menggunakan metode deskriptif, yaitu mendeskripsikan bagaimana strategi Musyrif dalam membentuk karakter kepemimpinan dan kemandirian siswa SMA Insan Cendekia Mandiri Boarding School Sidoarjo.

Sumber data wawancara dari penelitian ini adalah Supervisor Asrama SMA, Musyrif, dan pengurus Organisasi Asrama Santri. Selain itu, penulis juga mengambil data hasil wawancara alumni SMA ICMBS untuk mendukung hasil penelitian ini. Proses wawancara dimulai dari 29 Januari - 7 Februari 2020. Selain wawancara penulis juga melakukan observasi antara tanggal 7 Januari 2020 sampai dengan tanggal 4 Februari 2020. Hasil penelitian ini diperkuat dengan dokumendokumen yang berhubungan dengan aktifitas kegiatan Musyrif dalam membentuk karakter kepemimpinan dan kemandirian siswa, baik berupa foto, video rekaman, file dokumen, dan lainya.

Adapun teknik analisis data yang digunakan dalam penelitian ini adalah dengan (Darmadi, 2014):

1. Mengorganisir informasi

2. Membaca keseluruhan informasi dan memberi kode

3. Membuat suatu uraian secara terperinci dan detail mengenai kasus yang diteliti dan konteksnya

4. Peneliti menetapkan pola dan mencari hubungan antara beberapa kategori

5. Peneliti memberikan interpretasi dan mengembangkan generalisasi natural dari kasus baik untuk peneliti maupun untuk penerapannya pada kasus lain

6. Menyajikannya secara naratif . 
Jurnal Pendidikan Kewarganegaraan

Vol. 7 No. 1 Maret 2020

\section{Hasil dan Pembahasan}

Strategi Musyrif dalam membentuk karakter kepemimpinan dan kemandirian siswa SMA ICMBS terbagi menjadi dua, yaitu internal dan eksternal. Adapun strategi internal diintegrasikan dalam enam tahapan yakni; perencanaan (planning), pengajaran/ pengenalan nilai-nilai karakter (knowing), pelaksanaan (actuating), pengawasan (controlling), hadiah dan hukuman (reward and punishment) dan evaluasi (evaluation). Sedangkan strategi eksternal diimplementasikan dalam tiga tahapan yakni; pengenalan, pengawasan, dan evaluasi.

\section{Strategi internal}

Strategi perencanaan diawali dengan mengorganizing struktur kepengurusan asrama kedalam sembilan divisi yakni: ubudiyah, diniyah, tahfidz, bahasa, kesehatan, kebersihan, sarana prasarana, konsumsi, dan pengasuhan. selanjutnya adalah menentukan strategi pendidikan dan pembelajaran yang akan digunakan meliputi; tujuan, prinsip, alat yang digunakan, optimalisasi sarana prasarana, materi yang diberikan, kurikulum yang digunakan, pendekatan dan metode yang digunakan, dengan dikoordinir oleh divisi kurikulum diniyah.

Strategi pelaksanaan (actuating) diintegrasikan melalui aktivitas kegiatan. Berikut adalah strategi pelaksanaan pembentukan karakter kepemimpinan dan kemandirian siswa SMA Insan Cendekia Mandiri Boarding School, Sidoarjo.

Karakter dasar kepemimpinan yang menjadi fokus dalam penelitian ini berjumlah 18 karakter yaitu: Kejujuran, Adil, Musyawarah, Amar makruf nahi munkar, Cerdas, Visioner, Inisiatif, Ikhlas Berkorban, Bertanggung Jawab, Percaya Diri, Responsif,
Journal of Civics and Education Studies p-ISSN 2302-0865 | e-ISSN 2621-346X

Empati, Inovatif, Toleran, Sederhana, Efektif dan Efisien, Keteladanan, Terbuka.

Berikut strategi Musyrif dalam membentuk karakter kepemimpinan dalam diri siswa SMA ICMBS Sidoarjo:

a. Kejujuran

Adapun strategi Musyrif dalam membentuk karakter kejujuran adalah:

1). Melalui form kejujuran untuk puasa senin dan kamis

2). Pembiasaan untuk selalu berkata benar dan jujur.

3). Jika melakukan pelanggaran sedang maupun berat, siswa menulis kronologi kejadian dengan sebenar-benarnya

4). Siswa memberikan alasan dengan sebenar-benarnya jika hendak izin keluar

5). Siswa dilarang berkata kotor dan jorok sehingga terbiasa untuk berkata yang baik dan benar.

b. Adil

Adapun strategi Musyrif dalam membentuk karakter adil adalah:

1). Optimalisasi organisasi asrama ICMBS

2). Mengajarkan siswa untuk menjadi pendengar yang baik

3). Mengajarkan siswa untuk menghargai pendapat orang lain

4). Mengajarkan siswa agar memperlakukan orang lain sebagaimana dirinya ingin diperlakukan

5). Bersedia menerima sanksi dari musyrif jika melakukan pelanggaran, dalam hal ini mereka dididik untuk siap memimpin dan siap dipimpin.

c. Musyawarah

Adapun strategi Musyrif dalam membentuk karakter kepemimpinan yang demokratis dalam diri siswa SMA ICMBS yaitu:

1). Optimalisasi organisasi asrama ICMBS 
2). Mengajarkan siswa untuk saling menghargai, tidak acuh tak acuh

3). Mengajarkan siswa untuk menjauhi sikap sombong

4). Mengajarkan siswa untuk menyampaikan pendapat dengan cara yang baik dan sopan

5). Mengajarkan siswa untuk berlapang dada dalam menerima keputusan musyawarah

6). Adanya Musyawarah bersama satu angkatan satu minggu sekali

7). Keteladanan dari para Musyrif melalui Musyawarah di tempat terbuka setiap sore hari dan minggu.

d. Amar makruf nahi munkar

Adapun strategi Musyrif dalam membentuk karakter pemimpin yang senang melakukan amar makruf nahi mungkar dalam diri siswa SMA ICMBS diintegrasikan melalui:

1). Optimalisasi pendidikan akidah dan akhlak

2). Optimalisasi kegiatan sholat berjamaah di masjid, sholat tahajjud dan sholat Dhuha di masjid, berdoa sebelum dan sesudah makan, melaporkan kepada Musyrif halhal yang melanggar syariat dll.

3). Optimalisasi Organisasi Asrama ICMBS.

e. Cerdas

Adapun strategi Musyrif dalam membentuk karakter pemimpin yang cerdas diintegrasikan melalui:

1). Pendidikan entrepreneurship

2). Optimalisasi organisasi asrama icmbs

3). Pendidikan bahasa asing

4). Mengajarkan siswa untuk bisa menempatkan dirinya (makan di lantai)

5). Keterbukaan melalui kesempatan untuk berpendapat dan berargumen ketika berkumpul bersama Musyrif.

\section{f. Visioner}

Adapun strategi Musyrif dalam membentuk karakter pemimpin yang visioner diintegrasikan dengan mengoptimalkan peran dan fungsi Organisasi Asrama.

g. Inisiatif

Adapun strategi Musyrif dalam dalam membentuk karakter pemimpin yang berinisiatif diintegrasikan melalui:

1). Optimalisasi Organisasi Asrama Santri

2). Pendidikan entrepreneurship

3). Melatih siswa berpikir kritis

4). Menempatkan siswa sebagai mitra pendidik

5). Pendidikan olahraga.

h. Ikhlas Berkorban

Adapun strategi Musyrif dalam membentuk karakter pemimpin yang ikhlas berkorban diintegrasikan melalui:

1). Kegiatan iuran untuk hewan Qurban di hari raya Idul Adha

2). Pemberian tanggung jawab mendisiplinkan adik-adik kelas untuk pergi ke masjid

3). Mengingatkan adik-adik kelas untuk tidur tepat waktu yaitu jam sepuluh.

4). Membangunkan adik-adiknya untuk tahajud

5). Mengajarkan nilai qodo' dan qodar, artinya apapun yang terjadi itu atas kehendak Allah SWT.

6). Mengajarkan siswa untuk menjauhi perbuatan riya'.

i. Bertanggung Jawab

Adapun strategi Musyrif dalam membentuk karakter pemimpin yang bertanggung jawab diintegrasikan melalui:

1). Optimalisasi Organisasi Asrama Santri

2). Kewajiban siswa melaksanakan tugas piket kamar

3). Kewajiban siswa menjaga kebersihan baik didapur, lingkungan asrama dan ICMBS secara keseluruhan

4). Memanggil siswa yang tidak bertanggung jawab dalam menjaga kebersihan 
5). Menggunakan bahasa "tanggung jawab" terhadap kerusakan sarana prasarana bukan dengan "ganti rugi"

\section{j. Percaya Diri}

Adapun strategi Musyrif dalam membentuk karakter pemimpin yang percaya diri diintegrasikan melalui:

1). Optimalisasi kegiatan public speaking.

2). Optimalisasi Organisasi Asrama santri

3). Pendidikan Entrepreneurship

4). Memperbanyak kegiatan yang mengasah kemampuan individu

k. Responsif

Adapun strategi Musyrif dalam membentuk karakter pemimpin yang responsif di SMA ICMBS diintegrasikan dengan mengoptimalkan peran dan tugas Organisasi Asrama Santri.

\section{Empati}

Adapun strategi Musyrif dalam membentuk karakter pemimpin yang responsif di SMA ICMBS diintegrasikan melalui:

1). Pengaturan kamar siswa

2). Mengajari siswa untuk saling berbagi rezeki

3). Melatih siswa untuk bisa merasakan apa yang orang lain rasakan

4). Sholat ghoib dan tahlil secara berjamaah jika ada salah satu anggota atau saudaranya yang meninggal

5). Penguatan pendidikan dan pembelajaran diniyah.

m. Inovatif

Adapun strategi Musyrif dalam membentuk karakter karakter inovatif dalam diri siswa SMA ICMBS diintegrasikan melalui:

1). Mengajarkan siswa untuk berani mencoba, berani bertanggung jawab dan siap menerima resiko
2). Mendorong siswa untuk terus mencari pengetahuan-pengetahuan baru melalui optimalisasi perpustakaan

3). Mengajarkan siswa agar tidak cepat puas dengan keadaan saat ini

4). Mengajarkan siswa untuk bersikap terbuka dan beradaptasi dengan segala keadaan.

n. Toleran

Adapun strategi Musyrif dalam membentuk karakter karakter toleran dalam diri siswa SMA ICMBS diintegrasikan melalui:

1). Mengarahkan siswa untuk memperbanyak teman

2). Mengajarkan siswa tentang kebhinekaan

3). Mengajarkan siswa untuk senantiasa berpikir bijaksana

4). Mengajarkan siswa untuk tidak berpikiran sempit

5). Mengajarkan siswa bahwa manusia terlahir berbeda-beda dengan segala kelebihan dan kekurangan yang dimilikinya.

6). Mengajarkan siswa untuk senantiasa bermuhasabah diri.

o. Sederhana

Adapun strategi Musyrif dalam membentuk pemimpin yang berkarakter sederhana diintegrasikan dengan:

1). Mengajarkan siswa untuk bisa menyeimbangkan antara keinginan dan kemampuan juga antara keinginan dan kebutuhan

2). Kewajiban menabung dan apabila hendak mengambil untuk suatu keperluan wajib mendapatkan persetujuan dari Musyrif atau wali kelas.

3). Mengajarkan siswa untuk selalu berbagi

4). Mengajarkan tentang kepemilikan, serta melarang mengambil barang orang lain tanpa izin sang pemilik atau Ghosob. 


\section{p. Efektif dan Efisien}

Adapun strategi Musyrif dalam membentuk karakter pemimpin yang efektif dan efisien diintegrasikan dengan mengoptimalkan peran dan fungsi Organisasi Asrama Santri:

1). Keteladanan

Adapun strategi Musyrif dalam membangun karakter keteladanan siswa diintegrasikan dengan mengoptimalkan peran dan fungsi Organisasi Asrama Santri.

2). Terbuka

a) Adapun strategi Musyrif dalam membentuk sikap terbuka diintegrasikan dengan memberikan kesempatan pada siswa untuk berpendapat, berargumen serta memberikan masukan-masukan dengan cara yang baik dan sopan.

b) Pendidik berprinsip bahwa kedudukan peserta didik adalah sebagai mitra pendidik sehingga lebih bersifat terbuka

Dari penjelasan diatas dapat dikonklusikan bahwa kegiatan organisasi asrama ICMBS merupakan faktor dominan dalam membentuk karakter dasar kepemimpinan yaitu Adil, musyawarah, amar makruf nahi munkar, cerdas, visioner, inisiatif, ikhlas berkorban, tanggung jawab, percaya diri, resonsif, inovatif, efektif dan efisien, keteladanan, dan terbuka. sedangkan faktor lainnya melalui pemberian motivasi, pengenalan nilai-nilai karakter yang baik, multi aktivitas, kedisiplinan dan keteladanan.

Selanjutnya adalah strategi Musyrif dalam membentuk karakter kemandirian. Karakter kemandirian dalam penelitian ini adalah sebagaimana menurut Kementerian Pendidikan dan Kebudayaan (Kemendikbud, 2017) yaitu:

1) Etos kerja yang baik
2) Tangguh

3) Tahan banting

4) Memiliki daya juang yang tinggi

5) Profesional

6) Kreatif

7) Keberanian

8) Menjadi pembelajar sepanjang hayat.

Berikut strategi Musyrif dalam membentuk karakter kemandirian siswa SMA ICMBS Sidoarjo:

1) Etos kerja yang baik

Adapun strategi Musyrif dalam membentuk pemimpin yang memiliki etos kerja yang baik diintegrasikan dengan mendorong keaktifan siswa dalam Organisasi Asrama Santri.

2) Tangguh

Adapun strategi Musyrif dalam membentuk ketangguhan dalam diri siswa diintegrasikan dengan mendorong keaktifan siswa dalam Organisasi Asrama Santri.

3) Tahan banting

Adapun strategi Musyrif dalam membentuk karakter tahan banting diintegrasikan dengan mendorong keaktifan siswa dalam Organisasi Asrama Santri.

4) Berdaya juang tinggi

Adapun strategi Musyrif dalam membentuk siswa berdaya juang tinggi diintegrasikan dengan:

a) Mewajibkan siswa untuk mengikuti kegiatan ekstrakurikuler seni silat Perisai Diri

b) Mendorong keaktifan siswa dalam berorganisasi

5) Profesional

Adapun strategi Musyrif dalam membentuk sikap profesional dalam diri siswa diintegrasikan dengan:

a) Optimalisasi Organisasi Asrama ICMBS 
b) Kewajiban untuk selalu tepat waktu dalam melaksanakan tugas dan tanggung jawabnya. Misal tanggung jawab menghidupkan audio Qur'an menjelang sholat maghrib

6) Kreatif

Adapun strategi Musyrif dalam menumbuhkan sikap kreatif dalam diri siswa diintegrasikan dengan:

a) Optimalisasi perpustakaan ICMBS

Menurut penelitian Sigit Dwi Laksana (2019), dan Mahfud (2016) bahwa ketersediaan literasi yang cukup dengan didukung oleh teknologi yang memadai berpengaruh positif terhadap perkembangan berpikir siswa sehingga dengan berpikir tersebut dapat membentuk karakter kritis dan kreatif siswa.

b) Pendidikan kreasi seni melalui pembuatan film pendek

c) Pendidikan berwirausaha (entrepreneurship).

7). Keberanian

Adapun strategi Musyrif dalam membangun keberanian dalam diri siswa SMA ICMBS diintegrasikan dengan:

a) Optimalisasi Organisasi Asrama ICMBS

b) Memberikan kesempatan untuk berbicara di depan para jamaah di masjid

c) Memberikan tanggung jawab untuk mengatur ibadah sholat fardhu dan sholat tahajjud di masjid secara berjamaah

d) Memberikan tanggung jawab untuk mengawasi zikir bersama setelah sholat fardhu

e) Kegiatan penyembelihan binatang Qurban dihari raya idul adha

8). Menjadi pembelajar sepanjang hayat
Adapun strategi Musyrif dalam membentuk pribadi yang selalu belajar sepanjang hayat diintegrasikan dengan:

a) Penguatan pendidikan agama serta norma-norma yang berlaku di tengah masyarakat

b) Optimalisasi organisasi asrama ICMBS

c) Memotivasi peserta didik untuk senantiasa memperbaharui niat dalam menuntut ilmu

Dari penjelasan diatas dapat dikonklusikan bahwa kegiatan Organisasi Asrama ICMBS masih merupakan faktor dominan dalam membentuk karakter kemandirian, sedangkan faktor lainnya adalah melalui pemberian motivasi, tanggung jawab, pendidikan agama dan literasi, dan pendidikan ekstrakurikuler pencak silat.

Strategi pengawasan diintegrasikan melalui kerjasama yang kuat baik antar komponen lembaga pendidikan SMA ICMBS Sidoarjo meliputi: musyrif, guru sekolah, wali kelas, security, dan dengan peserta didik. Efektifitas pengawasan dilakukan dengan penguatan pendidikan amar makruf nahi mungkar dalam diri peserta didik melalui pembelajaran diniyah, taujihat wal irsyadat, dan pengawasan Musyrif dalam kehidupan sehari-hari siswa di asrama.

Strategi pemberian reward and punishment. Strategi pemberian reward dikelompokkan dalam dua bentuk yaitu materi dan immateri. Sedangkan strategi pemberian punishment diintegrasikan dengan berprinsipkan tidak menyentuh aspek fisik, lebih bersifat pada pembinaan. sedangkan, punishment untuk pelanggaran yang menimbulkan efek kerusakan diimplementasikan dengan ganti rugi.

Strategi evaluasi diintegrasikan melalui evaluasi antar Musyrif, Musyrif dan siswa, sedangkan evaluasi akhir semester 
Jurnal Pendidikan Kewarganegaraan

Vol. 7 No. 1 Maret 2020

diintegrasikan melalui Ujian diniyah yang termanifestasi dalam bentuk Raport Asrama.

\section{Strategi eksternal}

Strategi eksternal terbagi menjadi tiga yaitu pengenalan, pengawasan dan evaluasi.

a. Pengenalan (knowing) terbagi menjadi dua bentuk yaitu formal dan informal. Formal yaitu ketika wali murid menyerahkan anaknya kepada pihak sekolah dan asrama pada tahun ajaran baru, dan ketika pengambilan raport asrama dan sekolah, sedangkan informal ketika kegiatan penjengukan bulanan dan komunikasi aktif melalui media sosial (via wa group).

b. Pengawasan diintegrasikan melalui komunikasi aktif antara musyrif dengan orang tua/ wali santri, dan ketika siswa menjalani liburan ramadhan dan liburan pertengahan semester, dengan disertai kartu mutaba'ah.

c. Evaluasi terbagi menjadi dua bentuk yaitu formal dan informal. Formal diintegrasikan melalui pertemuan antara wali santri, musyrif dan manajer asrama sebagaimana pada tahap pengenalan (knowing), sedangkan informal diintegrasikan melalui komunikasi aktif via media sosial atau komunikasi telepon.

Musyrif berasal dari bahasa arab yakni syarufa yang berarti mulia dan Musyrif yang berarti pengawas atau pembimbing. Musyrif merupakan seorang pendidik, tetapi secara informal. Sebagaimana lazimnya seorang pendidik, Musyrif harus pula bisa menghandle permasalahan yang dihadapi oleh anak didiknya di asrama. Masyarakat menyebut Musyrif dengan pembina asrama. Dengan demikian musyrif memiliki peranan-peranan yang harus dapat dilakukan dalam melakukan bimbingan kepada para santri.
Journal of Civics and Education Studies p-ISSN 2302-0865 | e-ISSN 2621-346X

Berdasarkan konsep teori Djamarah tentang peranan guru atau Musyrif, menurut Syaiful Bahri, teori Djamarah adalah cara penyajian pelajaran, dimana peserta didik melakukan percobaan dengan mengalami dan membuktikan sendiri sesuatu yang dipelajari (Bahri Djamarah Syaiful dan Aswan Zain, Strategi Belajar ...., hlm.84”).

Teori ini mempunyai kelebihan dan kekurangan. Adapun kelebihan dari Teori Djamarah menurut Syaiful Bahri Djamarah sebagai berikut:

a. Kelebihan metode eksperimen antara lain:

1). membuat peserta didik lebih percaya atas kebenaran atau kesimpulan berdasarkan percobaannya

2). dalam membina peserta didik untuk membuat terobosan baru dengan penemuan dari hasil percobaannya dan bermanfaat bagi kehidupan manusia

3). hasil-hasil percobaan yang berharga dapat dimanfaatkan untuk kemakmuran umat manusia.

b. Kekurangan metode eksperimen antara lain:

1). metode ini lebih sesuai untuk bidang-bidang sains dan teknologi

2). metode ini memerlukan berbagai fasilitas peralatan dan bahan yang tidak selalu mudah diperoleh dan kadang kala mahal

3). metode ini menuntut ketelitian, keuletan, dan ketabahan

4). setiap percobaan tidak selalu memberikan hasil yang diharapkan karena mungkin ada faktor-faktor tertentu yang berada di luar jangkauan kemampuan atau pengendalian. 
Dengan demikian konsep teori Djamarah tersebut di atas, dapat dikonklusikan beberapa kegiatan yang berpengaruh besar dalam membentuk karakter kepemimpinan dan kemandirian siswa SMA ICMBS dalam penerapan strategi Musyrif. Kegiatan tersebut adalah Organisasi Asrama Santri. Organisasi tersebut berpengaruh dalam membentuk karakter-karakter dasar kepemimpinan seperti: Adil, musyawarah, amar makruf nahi munkar, cerdas, visioner, inisiatif, ikhlas berkorban, tanggung jawab, percaya diri, responsif, inovatif, efektif dan efisien, keteladanan, dan terbuka. Sedangkan dalam aspek kemandirian Organisasi Asrama berperan besar dalam membentuk etos kerja yang baik, ketangguhan, tahan banting, berdaya juang tinggi, profesional, keberanian dan menjadi pembelajar sepanjang hayat. Realitas tersebut senada dengan penelitian Indra Anggrio Toni dan Neni Mediatati, bahwa kegiatan organisasi siswa mampu membentuk karakter percaya diri dalam diri siswa, meningkatkan karakter tanggung jawab, dan disiplin (Toni, 2019). Demikian pula penelitian Intan Meutia dkk, bahwa kegiatan organisasi siswa berpengaruh besar dalam membentuk karakter kepemimpinan siswa (Meutia, Mulkan, \& Kurnisar, 2016).

Realitas diatas senada dengan hasil interview kami dengan ketua Organisasi Asrama Santri, Budi Pepriansyah, bahwa kegiatan organisasi asrama benar-benar membangun karakter tanggung jawab dalam dirinya, melatih kebijaksanaan dalam berpikir dan berpendapat, serta dalam mengambil keputusan (Budi Pepriansyah, (XI IIS, Ketua Organisasi Asrama), Wawancara, Sidoarjo. 5 Februari 2020). Sedangkan menurut Fajar Yulianto (Wawancara, 5 Februari 2020) organisasi asrama santri telah mendorong dirinya untuk menjadi uswah hasanah bagi anggota khususnya dalam kedisiplinan.

Hal senada juga diungkapkan oleh salah seorang alumni SMA ICMBS tahun 2018, Wahyu Syafiq Al Mughni yang saat ini belajar di Institut Pertanian Bogor, bahwa kegiatan organisasi asrama ICMBS berperan besar dalam membentuk karakter dasar kepemimpinan khususnya tanggung jawab dan keteladanan. Dalam aspek tanggung jawab "kami dididik untuk bertanggung jawab, bagaimana bisa menyelesaikan tugas organisasi sesuai deadline," sedangkan dalam aspek keteladanan "kalau menurut saya, (kegiatan organisasi SMA ICMBS) sangat berpengaruh karena disana kita dituntut untuk menjadi role model bagi yang lain, sebelum kita menyuruh orang lain, diri kita harus terlebih dahulu harus ngena (melakukan)". (Wawancara, 7 Februari 2020)

Kegiatan selanjutnya adalah pendidikan dan pembelajaran diniyah asrama. Kegiatan ini sangat urgent dalam menanamkan karakterkarakter dasar kepemimpinan dan kemandirian. Berdasarkan hasil analisis terhadap materi diniyah, dapat dikonklusikan bahwa pengenalan karakter kepemimpinan dan kemandirian yang diajarkan adalah karakter kepemimpinan dan kemandirian dalam perspektif pendidikan islam yang berpedomankan pada Al Qur'an dan Al Hadits. Menurut Yudi Wahyudin dan Mahipal (Wahyudin \& Mahipal, 2018), pendidikan kepemimpinan seperti ini sangatlah urgen guna melahirkan pemimpin yang berkarakter dan bervisi kuat.

Kegiatan selanjutnya adalah pendidikan entrepreneurship. Kegiatan tersebut berpengaruh besar dalam membangun karakter dasar kepemimpinan dan kemandirian yakni cerdas, inisiatif, percaya diri dan kreatif. Realitas tersebut senada dengan penelitian Azis, 
Rina Lelahester (2019) bahwa entrepreneurship berpengaruh besar dalam membangun karakter kepemimpinan dan kemandirian.

Kegiatan selanjutnya adalah public speaking untuk membangun karakter dasar pemimpin yakni percaya diri. Realitas ini senada dengan penelitian Unggul Wahyudi dkk, bahwa pelatihan public speaking yang diselenggarakan di Sekolah Dasar kemejing telah membangkitkan rasa percaya diri siswa, siswa menjadi lebih berani untuk mengungkapkan gagasan-gagasan yang dimilikinya, lebih berani berbicara depan umum sekalipun pada permulaanya perlu pemaksaan (Priyadi, Prabowo, \& Sari, 2013).

Menurut Iffa Dian Pratiwi \& Hermien Laksmiwati (Pratiwi \& Laksmiwati, 2016), terdapat korelasi yang signifikan antara kepercayaan diri seorang anak terhadap pembentukan karakter kemandirian anak. Jadi semakin tinggi kepercayaan diri seorang anak, semakin tinggi pula tingkat kemandiriannya. Dengan demikian kegiatan public speaking berpengaruh dalam membentuk karakter kepemimpinan dan kemandirian siswa.

Kegiatan selanjutnya adalah sholat berjamaah lima waktu dimasjid. Menurut Anik Kusnul Khotimah (Khotimah, 2017), pembiasaan shalat lima waktu berjamaah di masjid berpengaruh besar dalam membangun kesadaran shalat lima waktu. Jadi, apabila kewajiban terhadap tuhan dapat terpenuhi dengan baik, maka akan berefek pada kualitas implementasi tanggung jawab seorang pemimpin. Kegiatan tersebut juga memberikan pengaruh dalam membentuk karakter kemandirian seseorang, menurut Syafiq alumni SMA ICMBS 2018 "aktivitas yang membentuk kemandirian adalah seperti komitmen kita terhadap waktu, hubungan kita dengan tuhan seperti sholat lima waktu dan sholat sunnah, karena itu kita perlu pintar-pintar dalam mengatur waktu, bagaimana agar kita bisa bangun melaksanakan tahajud dengan baik". Dengan demikian pembiasaan shalat lima waktu berjamaah berpengaruh dalam membentuk karakter dasar kepemimpinan dan kemandirian.

Kegiatan selanjutnya adalah kontinuitas pendidikan toleransi yang diimplementasikan di ICMBS. Menurut Muhammad Syafiq Al Mughni (Alumni SMA ICMBS 2018), pendidikan toleransi di ICMBS membentuk siswa menjadi saling menghargai, saling menyeimbangi, menjunjung tinggi gotong royong, apalagi multikultural di ICMBS demikian tinggi, dimana siswa datang dari berbagai daerah.

Jika dikomparasikan dengan hasil penelitian Sayyida Farihatunnafsiyah \& Iwan Wahyu Widayat (2017). terkait strategi pembentukan karakter kepemimpinan di Tebuireng dimana strateginya dibentuk oleh empat aspek, yaitu lima dasar nilai pesantren Tebuireng, figur, proses, dan lingkungan maka dapat dikatakan proses pembentukan karakter di SMA ICMBS Sidoarjo juga mencakup figur, proses, dan lingkungan, hanya saja di Tebuireng menggunakan lima nilai dasar sebagai barometer kepemimpinan sedangkan di SMA ICMBS menggunakan dua nilai yaitu pemimpin yang berkarakter dan visioner. Jika dikomparasikan dengan hasil penelitian Sri Utaminingsih dkk (2017), terkait strategi penanaman pendidikan karakter berbasis Soft Skill dimana terdapat empat tahapan yaitu: planning, organizing, actuating, dan controlling, maka strategi pembentukan karakter kepemimpinan dan kemandirian di SMA ICMBS tergolong lebih lengkap dimana terdapat reward and punishment dan juga evaluasi.

Kemudian jika dikomparasikan dengan strategi pembentukan karakter perspektif 
Heritage Foundation maka strategi di SMA ICMBS yang perlu dibangun adalah pada point Characteristic of the students, yaitu mengetahui spesialisasi masing-masing peserta didik serta kompetensi yang dimilikinya, dan menerapkan kurikulum sembilan aspek kecerdasan manusia (di SMA ICMBS menggunakan 7 pilar Building Learning Power. Pendidikan Karakter dengan perspektif Heritage Foundation diajarkan melalui tahapan-tahapan:

a. Student active learning, contextual learning, inquiry based learning, and integrated learning yaitu menggunakan pembelajaran yang melibatkan keaktifan peserta didik, dan dengan memberikan materi pelajaran yang konkret, serta relevan dengan kehidupannya.

b. Correct area learning, value, safety, yaitu pembelajaran dalam lingkungan yang benar dan kondusif, memberikan rasa aman, serta menciptakan motivasi

c. Knowing the good, loving the good, and acting the good, yaitu mengajarkan pengetahuan yang baik, mencintai kebaikan, serta melakukan kebaikan secara eksplisit, sistematis, dan kontinyu)

d. Characteristic of the students, yaitu mengetahui spesialisasi masing-masing peserta didik serta kompetensi yang dimilikinya, dan menerapkan kurikulum sembilan aspek kecerdasan manusia.

e. Developmentally appropriate practices, yaitu memakai sistem penerapan pengembangan yang pas dan tepat

f. Trustworthies and supportive, menciptakan hubungan saling percaya dan saling mendukung di dalam lingkungan pendidikan

g. Good model, yaitu tenaga pendidik memberikan contoh dan teladan yang baik terhadap peserta didiknya. h. Democratic system, yaitu guru menerapkan sistem demokratis dalam pembelajaran pendidikan karakter, sehingga sekolah menjadi lingkungan yang demokratis dan menyelesaikan berbagai problematika secara demokratis

i. Socio - emotional learning, yaitu siswa mempelajari dan mempraktikkan keterampilan sosial emosional, seperti menghargai setiap orang berbicara, beradab terhadap guru dan orang yang lebih tua, tidak berbicara kasar dan lainnya

j. Moral issue, yaitu menjadikan peserta didik bagian dalam menyelesaikan problematika moral. Keterlibatannya akan menjadikan mereka prososial, moral manusia.

k. Meaningness task, yaitu guru memberikan berbagai tugas yang bermakna dan relevan

1. Attention of intellectual growing, ethic, and emotion, yaitu pendidik memberikan perhatian yang maksimal terhadap pertumbuhan intelektual peserta didik, etika serta emosi, sehingga tercapai kesuksesan bersama tanpa ada unsur dikotomi.

\section{Kesimpulan}

Berdasarkan analisis dari pada hasil penelitian ini maka dapat disimpulkan bahwa Strategi Musyrif dalam membentuk karakter kepemimpinan dan kemandirian siswa SMA Insan Cendekia Mandiri Boarding School, Sidoarjo yakni melalui; perencanaan (planning), pengajaran/ pengenalan nilai-nilai karakter (knowing), pelaksanaan (actuating), pengawasan (controlling), hadiah dan hukuman (reward and punishment) serta evaluasi (evaluation). Merupakan suatu hal yang sangat efektif dalam menerapkan strategi Musyrif 
Jurnal Pendidikan Kewarganegaraan

Vol. 7 No. 1 Maret 2020

untuk membentuk karakter kepemimpinan dan kemandirian siswa.

Kegiatan organisasi asrama ICMBS selama ini dapat membentuk karakter dasar kepemimpinan bagi para anak didik, yaitu Adil, musyawarah, amar makruf nahi munkar, cerdas, visioner, inisiatif, ikhlas berkorban, tanggung jawab, percaya diri, responsif, inovatif, efektif dan efisien, keteladanan, dan terbuka. Faktor penunjang yaitu, pemberian motivasi, pengenalan nilai-nilai karakter yang baik, multi activities, kedisiplinan dan keteladanan. Maka, penerapan strategi tersebut yang dilakukan oleh para Muysrif sangat berpengaruh pada karakter dan kepribadian para siswa, sehingga tujuan daripada sekolah menjadikan anak-anak berkarakter rahmatan lil alamin, yang memiliki nilai-nilai islam dan sikap-sikap pemimpin masa depan. Hal ini merupakan visi dan misi sekolah.

\section{Referensi}

Darmadi, H. (2014). Metode Penelitian Pendidikan Dan Sosial: Teori Konsep Dasar Dan Implementasi. Bandung: Alfabeta.

Galela, F. (2012). Pendidikan Pola Asrama dalam Upaya Meningkatkan Mutu Pendidikan Islam di Pesantren Hidayatullah Fakfak. UIN Alauddin Makassar.

Khotimah, A. khusnul. (2017). Pengaruh Pembiasaan Shalat Berjamaah Terhadap Kesadaran Shalat Lima Waktu Siswa MI Safinda Surabaya. Tadarus: Jurnal Pendidikan Islam, 6(1).

Laksana, S. D. (2019). Pendidikan Kreatif Berbasis Nilai-Nilai Islam Melalui Public Literacy. Jurnal Studi Kependidikan Dan Keislaman, 5(2), 205-215.
Journal of Civics and Education Studies p-ISSN 2302-0865 | e-ISSN 2621-346X

Mahfud. (2016). Berpikir Dalam Belajar; Membentuk Karakter Kreatif Peserta Didik. JURNAL AL TARBAWI AL HADITSAH, 1(1).

Meutia, I., Mulkan, M., \& Kurnisar. (2016). Pengaruh Kegiatan Anggota Pengurus Organisasi Siswa Intra Sekolah (OSIS) Terhadap Sikap Kepemimpinan Siswa Di SMA Negeri 10 Palembang. Jurnal Bhineka Tunggal Ika, 3(1), 65-70.

Pala, A. (2011). The Need For Character Education. International Journal of Social Sciences and Humanity Studies, $3(2)$.

Pelaksanaan Program Boarding School Dalam Pembinaan Moral Siswa Di Sma Taruna Indonesia Palembang. (2014).

Pratiwi, I. D., \& Laksmiwati, H. (2016). Kepercayaan Diri Dan Kemandirian Belajar Pada Siswa SMA Negeri 'X.' Jurnal Psikologi Teori Dan Terapan, $7(1)$,

https://doi.org/http://dx.doi.org/10.26740 /jptt.v7n1

Priyadi, U., Prabowo, W. A., \& Sari, D. M. (2013). Membangun Kepercayaan Diri Anak Melalui Pelatihan Public Speaking Guna Persiapkan Generasi Berkarakter. Jurnal Inovasi Dan Kewirausahaan, 2(2), 88-93.

Ridwan, A. S. Y., \& Rusdiana, S. (2018). Kebebasan Memilih Oihak Dalam Kontrak Pada Asas Kebebasan Berkontrak dalam Sewa Menyewa Kamar Tinggal. Jurnal Hukum Ius Quia Iustum.

https://doi.org/10.20885/iustum.vol25.iss 1.art6

Rina, L. (2019). STUDENT LEADERSHIP IN SCHOOL: INTERNALIZATION OF ENTREPRENEURIAL COMPETENCE AND CHARACTER. Jurnal Manajemen 
Jurnal Pendidikan Kewarganegaraan

Vol. 7 No. 1 Maret 2020

Dan Kewirausahaan, 21(1), 1-8. https://doi.org/10.9744/jmk.21.1.1-8

Rivai, V., Bachtiar, \& Amar, B. R. (2013). Pemimpin Dan Kepemimpinan Dalam Organisasi. Jakarta: Raja Grafindo Persada.

Rizkiani, A. (2012). Pengaruh Sistem Boarding School Terhadap Pembentukan Karakter Peserta Didik (Penelitian di Ma' Had Darul Arqam Muhammadiyah Daerah Garut). Jurnal Pendidikan Universitas Garut.

Suprawito. (2010). No TitleBoarding School Dalam Nation And Character Building Praja. Jurnal Penelitian Pendidikan, 11(2).

Tafsir, A. (2013). Ilmu Pendidikan Islam. Bandung: PT Remaja Rosdakarya.

Toni, I. A. (2019). Peranan Organisasi Siswa Intra Sekolah (OSIS) Dalam Membentuk Karakter Siswa Di SMK Negeri 2 Salatiga. Satya Widya, 35(1), 54-61. https://doi.org/10.24246/j.sw.2019.v35.i 1.p54-61

Utaminingsih, S., Utomo, S., \& Zamroni, E. (2017). STRENGTHENING OF INDONESIAN ISLAMIC CHARACTER THOUGH ISLAMIC
Journal of Civics and Education Studies p-ISSN 2302-0865 | e-ISSN 2621-346X

EDUCATION

MANAGEMENT

BASED OF SOFT SKILLS. ADDIN. https://doi.org/10.21043/addin.v11i1.203

Wahyudin, Y., \& Mahipal. (2018). PENDIDIKAN KEPEMIMPINAN DAN PEMBINAAN KARAKTER. Jurnal Cendekia Ihya, 1(1), 33-40.

Wijaya, Andi, M., Wahidin, U., \& Maulida, A. (2018). Upaya Musyrif Pondok Pesantren Dalam Pembentukan Kepribadian Muslim: Studi Kasus Pada Santri Ma'had Huda Islami Kabupaten Bogor Tahun Ajaran 2018-2019. Prosiding Al Hidayah Pendidikan Agama Islam.

Zainiyati, H. salamah. (2010). Model Dan Strategi Pembelajaran Aktif (Teori Dan Praktek Dalam Pembelajaran Pendidikan Agama Islam). Putra Media Nusantara Surabaya \& IAIN PRESS Sunan Ampel.

Zubaedi. (2011). Desain Pendidikan Karakter: Konsepsi Dan Aplikasinya Dalam Lembaga Pendidikan. Jakarta: Kencana Prenada Media Group. 